\title{
Quantitative and mechanistic insights into the key process in the rhizodeposited carbon stabilization, transformation and utilization of carbon, nitrogen and phosphorus in paddy soil
}

\author{
Tida Ge $\mathbb{D} \cdot$ Yu Luo $•$ Xinhua He
}

Received: 4 September 2019 / Accepted: 22 October 2019 /Published online: 11 November 2019

(C) Springer Nature Switzerland AG 2019

Rice (Oryza sativa L.) is the world's second most important cereal crop and a staple food for approximately $50 \%$ of the global population. Furthermore, the carbon (C) rhizodeposited from rice roots into paddy soil plays an important role in C sequestration (Huang et al. 2010; Tian et al. 2013; Wei et al. 2019), as this fraction represents an appreciable proportion (up to $0.52 \mathrm{Gt}$ of $\mathrm{CO}_{2}$ equivalents) of biosphere $\mathrm{CO}_{2}$ (Ge et al. 2012, 2015). Recent studies on rice have characterized the distribution of rhizodeposited $\mathrm{C}$ in different soil organic matter pools, as well as the interactions between soil physicochemical and microbial properties in the plantsoil-atmosphere continuum. Moreover, given the

Responsible Editor: Hans Lambers.

T. Ge $(\bowtie)$

Key Laboratory of Agro-ecological Processes in Subtropical Region, Institute of Subtropical Agriculture, Chinese Academy of Sciences, Changsha 410125 Hunan, China

e-mail: gtd@isa.ac.cn

Y. Luo

Institute of Soil and Water Resources and Environmental Science, Zhejiang Provincial Key Laboratory of Agricultural Resources and Environment, Zhejiang University, Zhejiang 310058

Hangzhou, China

$\mathrm{X} . \mathrm{He}$

College of Resources and Environment, Southwest University,

Beibei, Chongqing 400715, China

X. He $(\bowtie)$

School of Biological Sciences, University of Western Australia, Perth, WA 6009, Australia

e-mail: Xinhua.he@uwa.edu.au current trends in global climate, these studies have also examined how such properties are affected by agricultural practices, such as water management, fertilizer application, and cropping system, under global environmental change scenarios based on factors such elevated $\mathrm{CO}_{2}$ and temperature (Li et al., 2019).

This Special Issue S79 (Rice \& paddy soils) was conceived with the aim of bringing together a range of studies that can provide quantitative and mechanistic insights into the key processes involved in rhizodeposited $\mathrm{C}$ stabilization and primed organic matter mineralization in paddy soils, as well as the uptake and turnover of elements, particularly those of C, nitrogen $(\mathrm{N})$, and phosphorus (P), in these soils. These studies serve to illustrate how cutting-edge techniques, including isotopic $\left({ }^{13} \mathrm{CO}_{2}\right.$ and $\left.{ }^{15} \mathrm{~N}\right)$ labeling and biomarker (DNA-based stable isotope probing, DNA-SIP) and molecular biological (Illumina-based high-throughput sequencing) analyses have been applied to examine the effects of agricultural practices and global environmental change on source and sink relationships in the rice-paddy system.

From among the original 30 manuscripts that were submitted from groups around the world, 12 have been accepted for publication in this issue, and although all of these studies were performed China, each involved collaboration with international colleagues. The new findings presented in these papers will serve to enhance our current understanding of soil $\mathrm{C}, \mathrm{N}$, and $\mathrm{P}$ utilization and their associated biogeochemical processes, as well as providing insights into rice performance, particularly that linked with the emission of greenhouse gases such 
as nitrous oxide $\left(\mathrm{N}_{2} \mathrm{O}\right)$ and $\mathrm{C}$ sequestration via rhizodeposition in the rice-paddy system.

The two papers by Guo et al. (2019) and Lu et al. (2019), for example, respectively focus on N-use efficiency (NUE) and rice yield in response to agricultural practices, including $\mathrm{N}$ fertilization as $\mathrm{N}$-free control, farmers' fertilization practice, and optimal $\mathrm{N}$ management, and the external application of 1,2-benzenediol, catechin (a root-secreted phytotoxin), and a crystalline flavonoid compound $\left(\mathrm{C}_{15} \mathrm{H}_{14} \mathrm{O}_{6}\right)$. Guo et al. (2019) found that compared with the fertilization practices of farmers, optimal $\mathrm{N}$ management can enhance the $\mathrm{N}$ nutrient index, leaf area index, net photosynthetic rate, and grain weight of rice, as well as shortening the length of the grain-filling period, thereby promoting higher NUE and yield. Lu et al. (2019) demonstrate that under a rice-rice-rape rotation, compared with a $2.0 \mu \mathrm{mol} \mathrm{L}^{-1}$ or higher application of 1,2-benzenediol, the external application of $0.20 \mu \mathrm{mol} \mathrm{L}^{-1}$ 1,2-benzenediol significantly enhanced root $\mathrm{N}$ uptake, nitrate reductase and glutamine synthetase activities, and physiological NUE, and hence rice growth and yield.

In a further four papers, the authors examine nitrification activity in response to fertilization and temperature. Liu et al. (2018) show that in response to the addition of $\mathrm{N}$ and organic $\mathrm{C}$ (glucose) to two paddy soils ( $\mathrm{pH} 4.9$ and 6.2), heterotrophic nitrification and denitrification were the predominant processes contributing to $\mathrm{N}_{2} \mathrm{O}$ production, whereas a comparatively low soil $\mathrm{pH}$ was found to inhibit soil nitrification and the activity of ammonia oxidizers. However, on the basis of ${ }^{15} \mathrm{~N}$-labeled callus and acetylene inhabitation analyses, Liu et al. (2019a) showed autotrophic nitrification to be the primary determinant of $\mathrm{NH}_{3}$ release from rice callus and stimulated the growth of ammonia-oxidizing archaea (AOA) in a pH 6.9 paddy soil. Furthermore ${ }^{13} \mathrm{CO}_{2}$-DNA-SIP analysis indicated that the activity of AOA in soil was significantly greater than that of ammonia-oxidizing bacteria (AOB) in response to callus amendment. Zhang et al. (2019) also used ${ }^{13} \mathrm{CO}_{2}$ DNA SIP and high-throughput sequencing to examine the activities of paddy soil microbiota, and accordingly found that the autotrophic nitrification and growth of AOB were significantly stimulated at an elevated temperature of $20^{\circ} \mathrm{C}$ compared with $15^{\circ} \mathrm{C}$, and that there were shifts in active ammonia oxidizers from AOA to AOB and among nitrite-oxidizing bacteria from Nitrospira moscoviensis to Nitrospira japonica at $20^{\circ} \mathrm{C}$. In a further study, Liu et al. (2019b) demonstrated that fertilization resulted in significantly higher methane $\left(\mathrm{CH}_{4}\right)$ emission from a paddy soil, which could be attributed to a decrease in redox potential in the vicinity of roots and reduced concentrations of dissolved oxygen at the soil-water interface. As a consequence of the altered soil oxygen status, the activity of bacteria in the genera of Methanoregula (methanogens) and Methylococcus (type I methanotrophs) was stimulated, whereas that of bacteria in the genus Methylocystis (type II methanotrophs) was inhibited, thereby leading to an increase in $\mathrm{CH}_{4}$ emission.

The allocation of assimilated $\mathrm{C}$ in rice-paddy soil systems in response to fertilization and rice growth stage is a subject addressed in a further five papers published in this issue. In their study of the distribution and fates of photosynthesized C in rice, Xiao et al. (2019) demonstrated that $\mathrm{N}$ fertilization during the elongation stage enhanced the allocation of photosynthesized $\mathrm{C}$, whereas allocation was inhibited by fertilization during the heading stage. Examining the effects of two fertilization regimes ( $\mathrm{N}$ fertilization and no- $\mathrm{N}$ fertilization), Zang et al. (2019) found that ${ }^{13} \mathrm{C}$ rhizodeposition and its turnover rate were promoted to a greater extent by $\mathrm{N}$ fertilization, although both fertilization regimes resulted in a similar net accumulation of $\mathrm{C}$ in paddy soil. Furthermore, on the basis of $6-\mathrm{h}{ }^{13} \mathrm{CO}_{2}$ pulse labeling analyses during the tillering, elongation, heading, and filling growth stages, these authors observed marked decreases in both the $\mathrm{C}$ allocated to roots and $\mathrm{C}$ input into soil with a progression in rice growth. These finding were found to be consistent with previous observations, as confirmed by a literature survey covering 94 published studies. In their study on $\mathrm{C}$ allocation, Zang et al. (2019) observed no immediate effects on C allocation following $\mathrm{C}$ assimilation but found that all administered $\mathrm{C}$ remained below ground. They also found that during a single season of rice cultivation, the total belowground net $\mathrm{C}$ input in paddy soil reached between 630 and $1080 \mathrm{~kg} \mathrm{C} \mathrm{ha}^{-1}$, of which $160-330 \mathrm{~kg} \mathrm{C}^{-1}$ was rhizodeposited C. In addition, Luo et al. (2018) found that $\mathrm{N}$ fertilization promoted the incorporation of photosynthetically derived $\mathrm{C}$ into soil organic $\mathrm{C}$ in $0.25-2.0 \mathrm{~mm}$ large aggregates and the humic acid fraction These results thus indicate that $\mathrm{N}$ fertilization can influence the distribution of rhizodeposited $\mathrm{C}$ within soil organic $\mathrm{C}$ pools, and thereby determine the $\mathrm{C}$ sequestration potential of rice plants. In a further study, Zhao et al. (2018) demonstrated that the combined application of organic $\mathrm{C}$ (carboxymethyl cellulose) and 
mineral $\mathrm{N}\left(\left(\mathrm{NH}_{4}\right)_{2} \mathrm{SO}_{4}\right)$ altered the composition of the soil microbial community, including reductions in the populations of gram-positive bacteria and fungi, whereas sole $\mathrm{N}$ fertilization was found to stimulate the growth of gram-negative bacteria and actinomycetes. Furthermore, Atere et al. (2018) found that combined $\mathrm{C}$ and $\mathrm{N}$ fertilization promoted a decrease in the distribution of rhizodeposited $\mathrm{C}$ within soil organic $\mathrm{C}$ and microbial organisms by 0.68 - and 0.53 -fold, respectively. These authors also showed that with continuous rice growth after 6, 14, and 22 days of ${ }^{13} \mathrm{CO}_{2}$ labeling, smaller amounts of ${ }^{13} \mathrm{C}$ were incorporated into soil at the 6th and 14th days, regardless of whether the rice had been under an alternative wetting-drying (AWD) cycle or under continuous flooding $(\mathrm{CF})$. In the AWD treatment (6-8 days), potted rice plants were initially irrigated, and then subsequently dried until the moisture content was between $\sim 70 \%$ and $75 \%$ of the water-holding capacity, after which the plants were re-flooded, and the procedure repeated for three complete wetting-drying

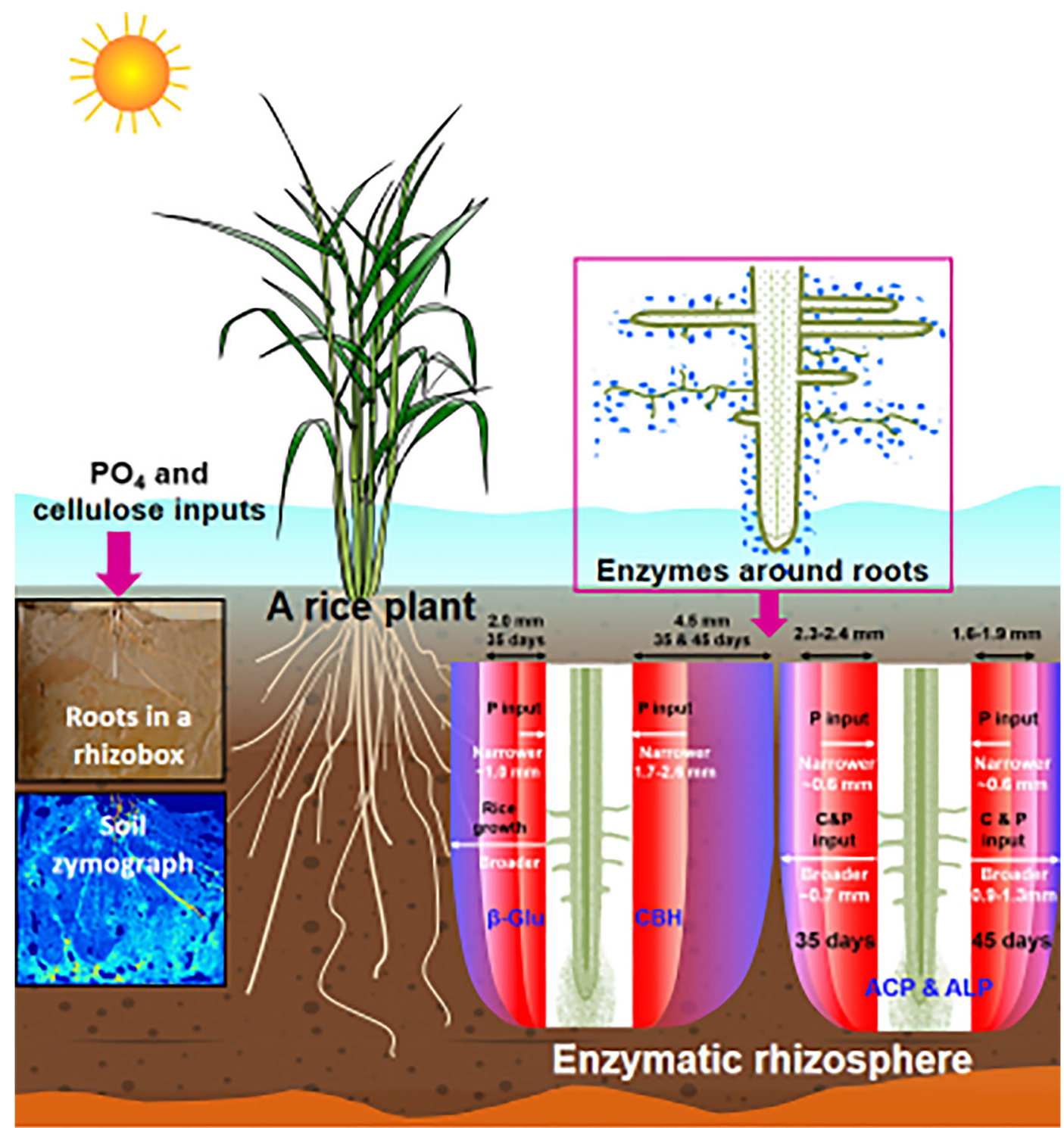

Fig. 1 A conceptional diagram showing the expansion of the enzymatic rhizosphere of rice as affected by carbon and phosphorus application and number of rice growth days (Modified from
Figs. 3 and 7 of Wei et al. 2018). Abbreviations: $\beta$-Glu, $\beta$ glucosidase; ACP, acid phosphatase; ALP, alkaline phosphatase; $\mathrm{CBH}$, cellobiohydrolase; and $\mathrm{PO}_{4}, \mathrm{NaH}_{2} \mathrm{PO}_{4}$ 
cycles. In contrast, compared with a no-P fertilization treatment, after 22 days of ${ }^{13} \mathrm{CO}_{2}$ labeling with $\mathrm{P}$ fertilization at a rate of $80 \mathrm{mg} \mathrm{P} \mathrm{kg}^{-1}$, new assimilation of $\mathrm{C}$ into $>250 \mu \mathrm{m}$ macroaggregates increased by $32 \%$ under AWD and $42 \%$ under CF. The authors found that the observed effects of $\mathrm{P}$ fertilization on the allocation of newly assimilated $\mathrm{C}$ into $250-53 \mu \mathrm{m}$ microaggregates and $<53 \mu \mathrm{m}$ silt + clay, which were respectively increased by $97 \%$ and $83 \%$ after 22 days of ${ }^{13} \mathrm{CO}_{2}$ labeling, was largely independent of water management. Furthermore, they demonstrated that $\mathrm{P}$ fertilization led to a higher incorporation of ${ }^{13} \mathrm{C}$ into the light fraction of rhizospheric soil (75\% at AWD and $90 \%$ at CF). The authors accordingly concluded that, compared with no P-fertilization, the application of $\mathrm{P}$ fertilizer in conjunction with the water-saving management of wetting and drying could enhance $\mathrm{C}$ sequestration in paddy soil.

In the final paper, Wei et al. (2018) describe their study of the enzymatic expansion of the rice rhizosphere using soil zymography (Fig. 1). They found that $\mathrm{P}$ fertilization narrowed the enzymatic rhizosphere, whereas the effects of cellulose addition and timing tended to be enzyme specific. During rice growth from 35 to 45 days after transplanting, there was an increase in the rhizospheric range of $\beta$ glucosidase ( $\beta$-Glu) from $1.0-2.6$ to $1.4-3.5 \mathrm{~mm}$, and a decrease in that of both acid and alkaline phosphatases (ACP and ALP), from 1.3 to $3.5 \mathrm{~mm}$, and cellobiohydrolase (CBH), from 1.5 to $4.5 \mathrm{~mm}$. In most cases, the rhizospheric ranges of ACP and ALP were found to be similar, and showed increases of $0.7-$ $1.3 \mathrm{~mm}$ and $0.9-1.3 \mathrm{~mm}$, respectively, after 35 and 45 days of rice growth in response to the application of mineral P + cellulose. Compared with no-P fertilization, $\mathrm{P}$ fertilization decreased the rhizospheric ranges of $\beta$-Glu, $\mathrm{CBH}$, and phosphatases by $\sim 1.0,1.7-2.6$, and $\sim 0.6 \mathrm{~mm}$, respectively. The authors accordingly concluded that the combined effect of $\mathrm{P}$ and $\mathrm{C}$ plays an important role in determining a broadening of the "rhizosphere effect" with respect to enzyme activity.

Finally, as guest editors, we would like to express our sincere thanks to all the authors who submitted their manuscripts, irrespective of whether or not these were eventually accepted for publication in this special issue. We also wish to express are gratitude to all the reviewers, responsible editors, the Editor-in-Chief Hans Lambert, and Lieve Bultynck and Archie Miras from Plant and Soil for their continuous assistance in making this special issue a success.

\section{References}

Atere CT, Ge TD, Zhu ZK, Liu SL, Huang XZ, Shibsitova OL, Guggenberger G, Wu JS (2018) Assimilate allocation by rice and carbon stabilisation in soil: effect of water management and phosphorus fertilisation. Plant Soil:1-15. https://doi. org/10.1007/s11104-018-03905-x

Ge TD, Yuan HZ, Zhu HH, Wu XH, Nie SA, Liu C, Tong CL, Wu JS, Brookes PC (2012) Biological carbon assimilation and dynamics in a flooded rice-soil system. Soil Biol Biochem 48:39-46. https://doi.org/10.1016/j.soilbio.2012.01.009

Ge TD, Liu C, Yuan HZ, Zhao ZW, Wu XH, Zhu ZK, Brookes PC, Wu JS (2015) Tracking the photosynthesized carbon input into soil organic carbon pools in a rice soil fertilized with nitrogen. Plant Soil 392:17-25. https://doi.org/10.1007 /s11104-014-2265-8

Guo JX, Yang SN, Guo LM, Lu Z, Guo JJ, Sun YM, Kong YL, Liang N, Shen QR, Guo SW (2019) Nitrogen nutrient index and leaf function affect rice yield and nitrogen efficiency. Plant Soil. https://doi.org/10.1007/s11104-019-04076-Z

Huang S, Rui WY, Peng XX, Huang QR, Zhang WJ (2010) Organic carbon fractions affected by long-term fertilization in a sub-tropical paddy soil. Nutr Cycl Agroecosyst 86:153160. https://doi.org/10.1007/s10705-009-9279-2

Li Y, Pan F, Yao H (2019) Response of symbiotic and asymbiotic nitrogen fixing microorganisms to nitrogen fertilizer application. Journal Soil Sedi 19:1948-1958. https://doi. org/10.1007/s11368-018-2192-Z

Liu HY, Ding Y, Zhang QC, Liu XM, Xu JM, Li Y, Di HJ (2018) Heterotrophic nitrification and denitrification are the main sources of nitrous oxide in two paddy soils. Plant Soil:1-15. https://doi.org/10.1007/s11104-018-3860-x

Liu HY, Pan H, Hu HW, Jia ZJ, Zhang Q, Liu YM, Di HJ, Li Y (2019a) Autotrophic archaeal nitrification is preferentially stimulated by rice callus mineralization in a paddy soil. Plant Soil:1-15. https://doi.org/10.1007/s11104-019-04164-0

Liu J, Zang HD, Xu HS, Zhang K, Jiang Y, Hu YG, Zeng ZH (2019b) Methane emission and soil microbial communities in early rice paddy as influenced by urea-N fertilization. Plant Soil. https://doi.org/10.1007/s11104-019-040910

Lu S, Song HX, Guan CY, Lepo JE, Wu ZM, He XH, Zhang ZH (2019) Long-term rice-rice-rape rotation optimizes 1,2benzenediol concentration in rhizosphere soil and improves nitrogen use efficiency and rice growth. Plant Soil:1-15. https://doi.org/10.1007/s11104-019-04177-9

Luo Y, Zhu ZK, Liu SL, Peng PQ, Xu JM, Brookes PC, Ge TD, Wu JS (2018) Nitrogen fertilization increases rice rhizodeposition and its stabilization in soil aggregates and the humus fraction. Plant Soil:1-11. https://doi.org/10.1007 /s11104-018-3833-0

Tian J, Pausch J, Fan MS, Li XL, Tang QY, Kuzyakov Y (2013) Allocation and dynamics of assimilated carbon in rice-soil system depending on water management. Plant Soil 363: 273-285. https://doi.org/10.1007/s11104-012-1327-Z

Wei XM, Ge TD, Zhu ZK, Hu YJ, Liu SL, Li Y, Wu JS, Razavi BS (2018) Expansion of rice enzymatic rhizosphere: temporal dynamics in response to phosphorus and cellulose application. Plant Soil:1-13. https://doi.org/10.1007/s11104-01803902-0 
Wei XM, Zhu ZK, Wei L, Wu JS, Ge TD (2019) Biogeochemical cycles of key elements in the paddy-rice rhizosphere: microbial mechanisms and coupling processes. Rhizosphere 10: 100145. https://doi.org/10.1016/j.rhisph.2019.100145

Xiao ML, Zang HD, Liu SL, Ye RZ, Zhu ZK, Su YR, Wu JS, Ge TD (2019) Nitrogen fertilization alters the distribution and fates of photosynthesized carbon in rice - soil systems : a ${ }^{13} \mathrm{C}_{-} \mathrm{CO}_{2}$ pulse labeling study. Plant Soil:1-12. https://doi. org/10.1007/s11104-019-04030-Z

Zang HD, Xiao ML, Wang YD, Ling N, Wu JS, Ge TD, Kuzyakov Y (2019) Allocation of assimilated carbon in paddies depending on rice age, chase period and $\mathrm{N}$ fertilization : experiment with ${ }^{13} \mathrm{CO}_{2}$ labelling and literature synthesis. Plant Soil:1-11. https://doi.org/10.1007/s11104-019-03995-1
Zhang Q, Li Y, He Y, Brookes PC, Xu JM (2019) Elevated temperature increased nitrification activity by stimulating AOB growth and activity in an acidic paddy soil. Plant Soil:1-13. https://doi.org/10.1007/s11104-019-04052-7

Zhao ZW, Ge TD, Gunina A, Li YH, Zhu ZK, Peng PQ, Wu JS, Kuzyakov Y (2018) Carbon and nitrogen availability in paddy soil affects rice photosynthate allocation, microbial community composition and priming : combining continuous C labeling with PLFA analysis. Plant Soil:1-16. https://doi.org/10.1007/s11104-018-3873-5

Publisher's note Springer Nature remains neutral with regard to jurisdictional claims in published maps and institutional affiliations. 